\title{
Thermal tracing of retained meltwater in the lower accumulation area of the Southwestern Greenland ice sheet
}

\author{
Charalampos CHARALAMPIDIS, ${ }^{1,2}$ Dirk VAN AS, ${ }^{1}$ William T. COLGAN, ${ }^{1,3}$ \\ Robert S. FAUSTO, ${ }^{1}$ Michael MACFERRIN, ${ }^{4}$ Horst MACHGUTH ${ }^{1,5}$ \\ ${ }^{1}$ Geological Survey of Denmark and Greenland (GEUS), Øster Voldgade 10, 1350 Copenhagen K, Denmark \\ E-mail: cc@geus.dk \\ ${ }^{2}$ Department of Earth Sciences, Uppsala University, Villavägen 16, 75236 Uppsala, Sweden \\ ${ }^{3}$ Department of Earth and Space Sciences and Engineering, York University, 4700, Keele Street, M3J 1P3 Toronto, Canada \\ ${ }^{4}$ Cooperative Institute for Research in Environmental Sciences (CIRES), 216 UCB, University of Colorado Boulder, Boulder, \\ CO 80309, USA \\ ${ }^{5}$ Arctic Technology Centre (ARTEK), Technical University of Denmark, Brovej, byg. 118, 2800, Kgs Lyngby, Denmark
}

\begin{abstract}
We present in situ firn temperatures from the extreme 2012 melt season in the southwestern lower accumulation area of the Greenland ice sheet. The upper $2.5 \mathrm{~m}$ of snow and firn was temperate during the melt season, when vertical meltwater percolation was inefficient due to a $\sim 5.5 \mathrm{~m}$ thick ice layer underlying the temperate firn. Meltwater percolation and refreezing beneath $2.5 \mathrm{~m}$ depth only occurred after the melt season. Deviations from temperatures predicted by pure conductivity suggest that meltwater refroze in discrete bands at depths of 2.0-2.5, 5.0-6.0 and 8.0-9.0 m. While we find no indication of meltwater percolation below $9 \mathrm{~m}$ depth or complete filling of pore volume above, firn at 10 and $15 \mathrm{~m}$ depth was respectively $4.2-4.5^{\circ} \mathrm{C}$ and $1.7^{\circ} \mathrm{C}$ higher than in a conductivity-only simulation. Even though meltwater percolation in 2012 was inefficient, firn between 2 and $15 \mathrm{~m}$ depth the following winter was on average $4.7^{\circ} \mathrm{C}$ warmer due to meltwater refreezing. Our observations also suggest that the 2012 firn conditions were preconditioned by two warm summers and ice layer formation in $\mathbf{2 0 1 0}$ and 2011. Overall, firn temperatures during the years 2009-13 increased by $0.6^{\circ} \mathrm{C}$.
\end{abstract}

KEYWORDS: Greenland ice sheet, accumulation area, firn, percolation, refreezing, superimposed ice

\section{INTRODUCTION}

In recent years, the air or surface temperatures of the Greenland ice sheet have increased (Van As, 2011; Hall and others, 2013), contributing to accelerated mass loss (Shepherd and others, 2012). Increases in surface runoff accounted for two-thirds of ice-sheet mass loss between 2009 and 2012 (Enderlin and others, 2014). During the summer of 2012 the atmosphere was exceptionally warm over the ice sheet (Bennartz and others, 2013; Tedesco and others, 2013), resulting in an exceptional surface melt extent that was unprecedented during the observational period. Around 12 July 2012, melt was observed across $98.6 \%$ of the ice-sheet area, including Summit $\left(72^{\circ} 35^{\prime}\right.$ $46.4^{\prime \prime} \mathrm{N} ; 38^{\circ} 25^{\prime} 19.1^{\prime \prime} \mathrm{W}$ ), the highest location on the ice sheet at $\sim 3216 \mathrm{~m}$ above sea level (a.s.l.), where nearsurface hourly air temperature reached $0.8^{\circ} \mathrm{C}$ (Nghiem and others, 2012; McGrath and others, 2013). Summit was relatively warm throughout the summer of 2012, with the highest June-August (JJA) average air temperature $\left(-11.4^{\circ} \mathrm{C}\right)$ observed since 1994 (Hanna and others, 2014). Ice core evidence suggests that melting at Summit had previously not occurred since 1889 (Clausen and others, 1988; Keegan and others, 2014).

The refreezing, and thus retention, of meltwater in firn can potentially buffer the Greenland ice sheet's meltwater runoff contribution to sea level rise (Pfeffer and others, 1991; Bøggild and others, 2005; Harper and others, 2012; Humphrey and others, 2012). Using regional climate simulations, Van Angelen and others (2013) suggest that during recent decades, $42 \pm 4 \%$ of all rain falling on, and meltwater generated at, the ice-sheet surface was ultimately retained within the firn. Future Arctic climate change, however, will likely result in more frequent and intense ice-sheet melt and runoff episodes, forcing snow facies to migrate to higher elevations (McGrath and others, 2013). Van Angelen and others (2013) suggest that a moderate warming of air temperatures could cause a $50 \%$ reduction in ice-sheet wide firn retention capacity by 2100 . However, estimates of the fractional retention of melt, based on surface mass budget (SMB) reconstructions, are quite diverse and fairly uncertain (Vernon and others, 2013). In addition, there is only an emerging understanding of the role of perennial firn aquifers in buffering the transient response of ice sheet runoff to climate change (Koenig and others, 2014).

Firn temperature evolution can be interpreted by means of heat transfer simulations. In the interior of the ice sheet, firn temperatures are almost exclusively controlled by heat conduction (Cuffey and Paterson, 2010). Field observations from these areas, which experience no or limited meltwater refreezing, confirm that the annual temperature cycle does not penetrate below $20 \mathrm{~m}$ depth (Cuffey and Paterson, 2010). In the historic dry firn area, Benson (1962) found that temperatures at $10 \mathrm{~m}$ depth were generally within $0.3^{\circ} \mathrm{C}$ of average annual near-surface air temperature. Recent increases in melt and refreezing, however, have resulted in substantial latent heat release in, and consequent warming of, this near-surface firn. The top $10 \mathrm{~m}$ of firn at mid-elevations $(1400-2500 \mathrm{~m})$ in Northwest Greenland is now up to $5.7^{\circ} \mathrm{C}$ warmer than in the 1950s (Polashenski and others, 2014). In 
addition, the inland propagation of annually persistent hydrologic networks, which can facilitate cryo-hydrologic warming, may potentially moderate the historic cooling of firn or ice during the winter (Phillips and others, 2010, 2013; Lüthi and others, 2015).

The firn properties of the lower accumulation area (LAA) on the southwestern part of the ice sheet are particularly sensitive to climate change, as South and West Greenland have been subjected to relatively high air temperatures in recent melt seasons. It appears that analogous to processes observed on Arctic ice caps (Bezeau and others, 2013; Gascon and others, 2013), a succession of relatively high melt years, with relatively high corresponding meltwater retention, can cause a relatively rapid reduction in the pore volume available in near-surface firn (De la Peña and others, 2015). Once developed, this pore volume reduction can in turn hamper percolation, and thus favor meltwater runoff, in subsequent years (Machguth and others, 2016).

We seek to provide a detailed description of the roles of meltwater percolation and refreezing, as well as limits and delays in each, in preconditioning firn for runoff in the seldom-investigated LAA of the southwestern ice sheet. Here, we present firn temperatures from the KAN_U automatic weather station (AWS), which is located at $67^{\circ} 0^{\prime} \mathrm{N}$ and $47^{\circ} 1^{\prime} \mathrm{W}$, at $1840 \mathrm{~m}$ a.s.l. (Van As and others, 2013, 2014; Figs 1 and 2). These measurements cover the period from 4 April 2009 until 22 September 2013. Additional firn temperatures were recorded from 2 May 2012 until 1 February 2013. Following Pfeffer and Humphrey (1996), we infer the timing and depth of meltwater retention within the uppermost $15 \mathrm{~m}$ of the firn column during the 2012 melt season based on the thermal evolution of the firn. We use a conductivity model to identify thermal anomalies

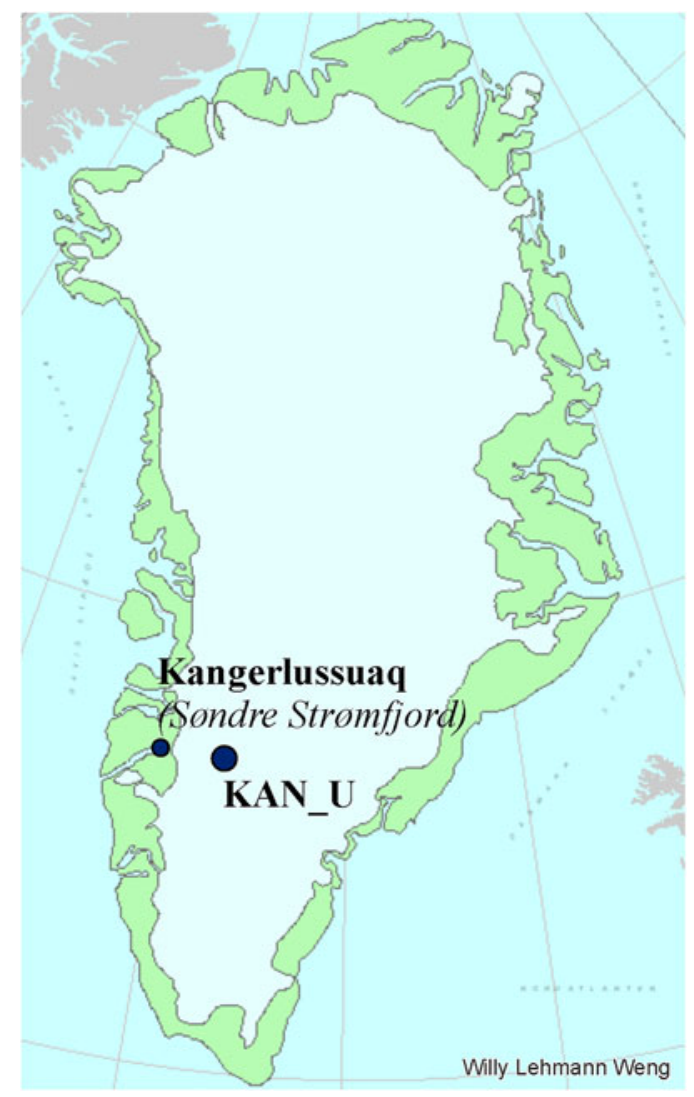

Fig. 1. Map of Greenland and the location of the KAN_U AWS. associated with refrozen meltwater. We also discuss $10 \mathrm{~m}$ firn temperatures in the southwestern LAA.

\section{METHODS}

\section{Site setting}

In the Kangerlussuaq region, the long-term equilibrium line altitude (ELA), where annual accumulation equals annual ablation, based on 21 years (1990-2011) of observations, is estimated at $1553 \mathrm{~m}$ a.s.l. (Van de Wal and others, 2012). Considering as reference for the highest elevation of the percolation zone the elevation at Saddle (2467 $\mathrm{m}$ a.s.l.; 65 $55^{\circ}$ $59^{\prime \prime} \mathrm{N}$; $\left.44^{\circ} 30^{\prime} 06^{\prime \prime} \mathrm{W}\right)$, located at the ice divide, the KAN_U site is located in the lower $30 \%$ of the percolation zone. SMB observations have been conducted at KAN_U since 1994 (Van de Wal and others, 2012). The average annual SMB over the period 1994-2010 was +0.27 m water equivalent (w.e.), with a positive SMB in all years. In contrast, the average annual SMB for the period 2009-12 was $-0.06 \mathrm{~m}$ w.e. (Charalampidis and others, 2015). For the latter period, the average annual $\sim 2 \mathrm{~m}$ air temperature was $-15^{\circ} \mathrm{C}$.

Van As and others (2012) suggest that 2009 was representative of the 1974-2010 average summer temperature and melt season duration at KAN_U. In summer 2010, relatively high air temperatures resulted in nearly twice as much surface melt at KAN_U as in 2009 (Charalampidis and others, 2015). Charalampidis and others (2015) compared the approximately equally warm summers of 2010 and 2012 at KAN_U and showed that 2012 melt exceeded 2010 melt by $\sim 40 \%$, primarily due to the melt-albedo feedback (Box and others, 2012).

The Snow Processes in the Lower Accumulation Zone (SPLAZ) campaign was conducted at KAN_U during the first week of May 2012, during which firn stratigraphy and density were determined from a $10.68 \mathrm{~m}$ long core. Stratigraphy was assessed at $1 \mathrm{~cm}$ vertical resolution by visual inspection. The cores were sampled for density at $10 \mathrm{~cm}$ vertical resolution with an $8-10 \mathrm{~kg} \mathrm{~m}^{-3}$ uncertainty (weighing scale accuracy: $5 \mathrm{~g}$ ). Measured firn density $(\rho)$ between 0.8 and $1.7 \mathrm{~m}$ depth was $\sim 530 \mathrm{~kg} \mathrm{~m}^{-3}$. At 1.7-7.5 m depth, thick ice lenses $\left(\rho>800 \mathrm{~kg} \mathrm{~m}^{-3}\right)$ were present, resulting in relatively little available pore volume. Approximately $0.8-0.9 \mathrm{~m}$ of snow $(0.25 \pm 0.08 \mathrm{~m}$ w.e. $)$, equivalent to $66 \%$ of the 2009-13 average, had accumulated on top of the firn during winter 2011/12. Relatively high air temperatures throughout June and early July 2012 melted this snowpack completely (Charalampidis and Van As, 2015). Firn densities and stratigraphy were subsequently re-assessed at $K A N \_U$ in the last week of April 2013, from a 19.12 m long firn core drilled in the framework of the Arctic Circle Traverse 2013 (ACT-13) campaign. The 2013 firn core further revealed the presence of pore volume below $7.5 \mathrm{~m}$ depth with respect to the surface height in May 2012 (Machguth and others, 2016).

\section{Firn temperature observations}

Firn temperatures at KAN_U were measured by a $10 \mathrm{~m}$ long thermistor string with $1 \mathrm{~m}$ vertical spacing between 1 and 7 $\mathrm{m}$ and an eighth thermistor at $10 \mathrm{~m}$ (Citterio and others, 2015). One of the main objectives of the 2012 SPLAZ campaign was to establish an additional firn monitoring station with three higher-resolution thermistor strings $\sim 50 \mathrm{~m}$ from 


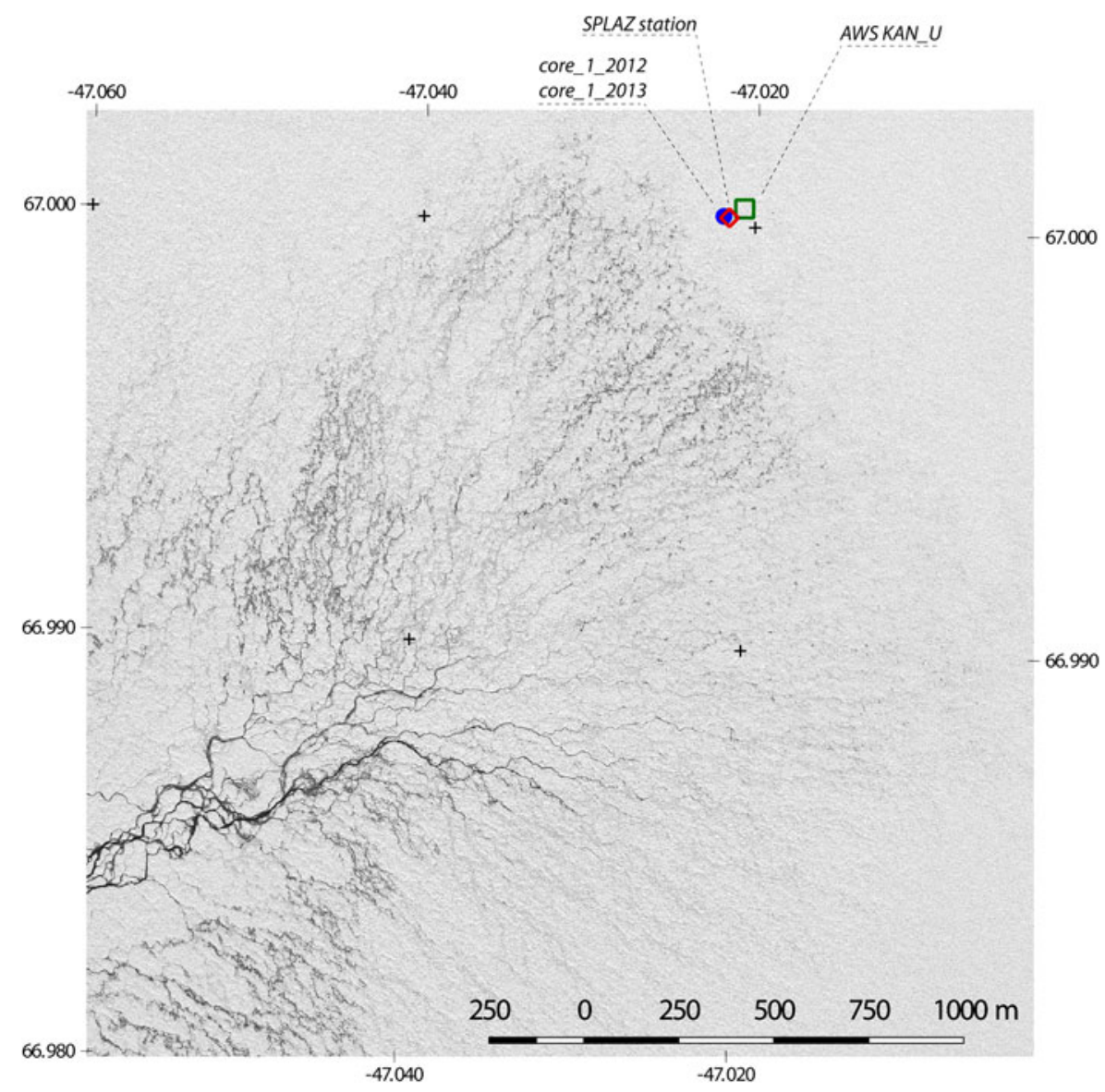

Fig. 2. Satellite image (WorldView1, panchromatic, $0.5 \mathrm{~m}$ spatial resolution) showing the area around the study site on 12 August 2012 . A snowfall event on August 6 and 7 covered smaller melt channels and slush fields, but enhanced contrast of the larger melt features.

KAN_U (Fig. 2). Two of these thermistor strings were $10 \mathrm{~m}$ long, with $0.5 \mathrm{~m}$ vertical spacing between thermistors above $5 \mathrm{~m}$ depth and $2.5 \mathrm{~m}$ vertical spacing below $5 \mathrm{~m}$ depth. The third (main) string was $15 \mathrm{~m}$ long with $0.25 \mathrm{~m}$ vertical spacing between 1 and $3.5 \mathrm{~m}$ depth, $0.5 \mathrm{~m}$ vertical spacing between 3.5 and $10 \mathrm{~m}$ depth, and $2.5 \mathrm{~m}$ vertical spacing below $10 \mathrm{~m}$ depth (Figs $3 \mathrm{a}-\mathrm{c}$ ).

The SPLAZ station used RS $100 \mathrm{k} \Omega$ negative-temperature coefficient thermistors, which have a thermal time constant of $10 \mathrm{~s}$ and a reported uncertainty of $\pm 0.2^{\circ} \mathrm{C}$ at temperatures below $0^{\circ} \mathrm{C}$. The SPLAZ station also monitored: (i) snow temperatures by six high-precision temperature probes (107 Campbell Scientific; Charalampidis and Van As, 2015), (ii) air temperature via a radiation-shielded 107 Campbell probe, (iii) surface height via an SR50-L sonic ranger and (iv) surface temperature via a downward-facing Eppley PIR longwave radiation sensor. Measurements were collected at 10 min time intervals over a period of 9 months following installation. During the period of observations, three thermistors failed.

Due to ablation, the depth of all thermistors relative to the ice-sheet surface decreased during the melt season. The surfacing of individual thermistors from the SPLAZ station was determined by sonic ranger measurements, and thermistor temperatures thereafter are not considered for this study. The analogous KAN_U firn temperature thermistor data were treated similarly, with the exception that the depths of the KAN_U thermistors were determined by using the simulated surface height change from a validated surface energy-balance model forced by the KAN_U meteorological measurements (Charalampidis and others, 2015).

\section{Firn conductivity and density model}

In addition to heat conducted from the surface, latent heat released from refreezing meltwater and heat conducted at depth influence the energy transfer in firn during a melt season. To deconvolute these processes and qualitatively identify the depths at which refreezing occurred in 2012, we utilize a one-dimensional (1-D) heat conduction model that employs an explicit, central-difference Euler numerical scheme to calculate heat conduction, and subsequently attribute discrepancies between this simulated pure conduction profile and the observed profile to refreezing. We ignore horizontal advection and local heat production, which are generally considered negligible in near-surface snow and firn (Pfeffer and Humphrey, 1996).

Measured surface temperature and surface height change are used as boundary conditions in our heat conduction model, which has a spatiotemporal resolution of $0.1 \mathrm{~m}$ (to $15 \mathrm{~m}$ depth) and $10 \mathrm{~min}$. The specific heat capacity of firn is computed using a conventional temperature-dependent parameterization (Yen, 1981), and effective thermal conductivity is similarly updated as a function of firn density (Sturm and others, 1997). The initial firn density profile is prescribed based on firn core densities observed prior to the onset of the 2012 melt season. The firn temperature profile is initialized daily, using the observed temperature profile measured at 00.00 UTC and cubically interpolated in the vertical.

At the end of each day, differences between the simulated and measured firn temperature profiles are used to quantify latent heat release due to refreezing (Pfeffer and Humphrey, 


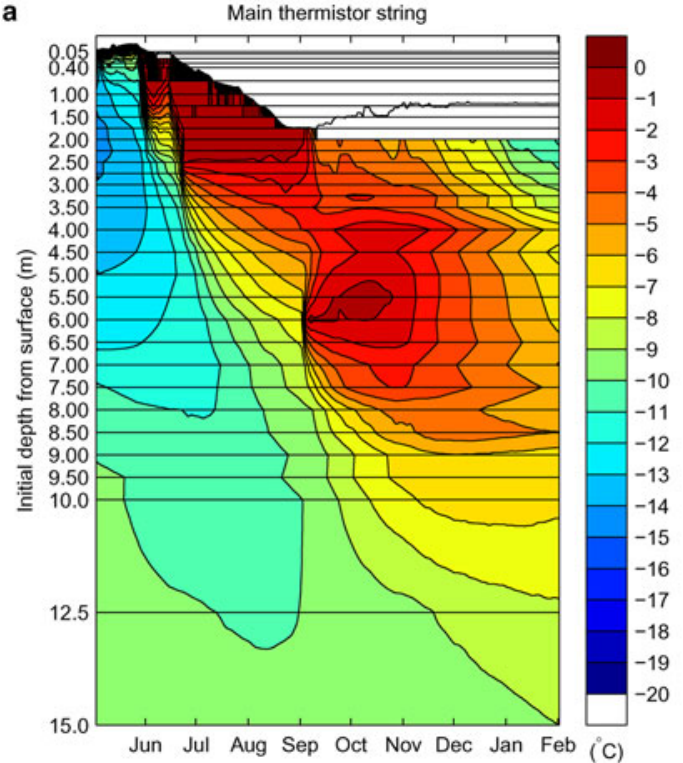

c

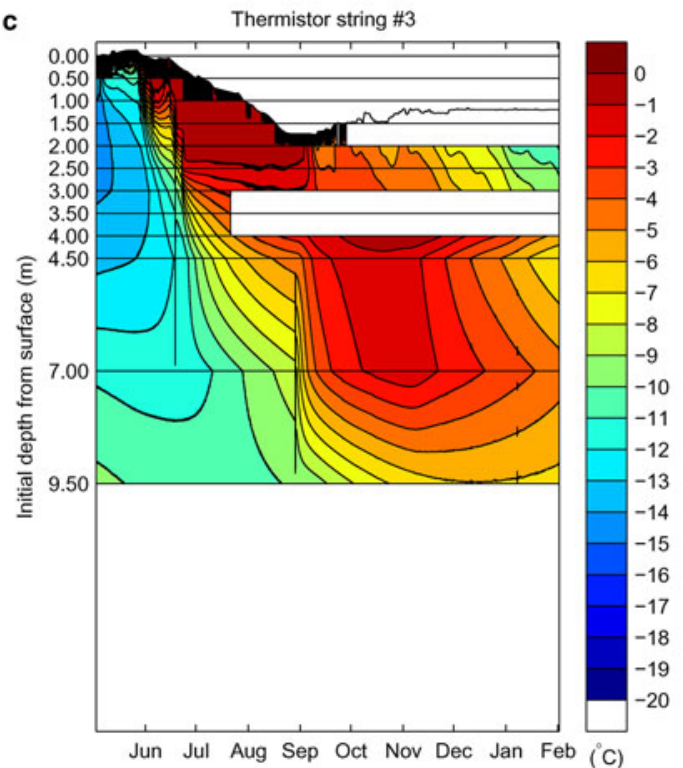

b

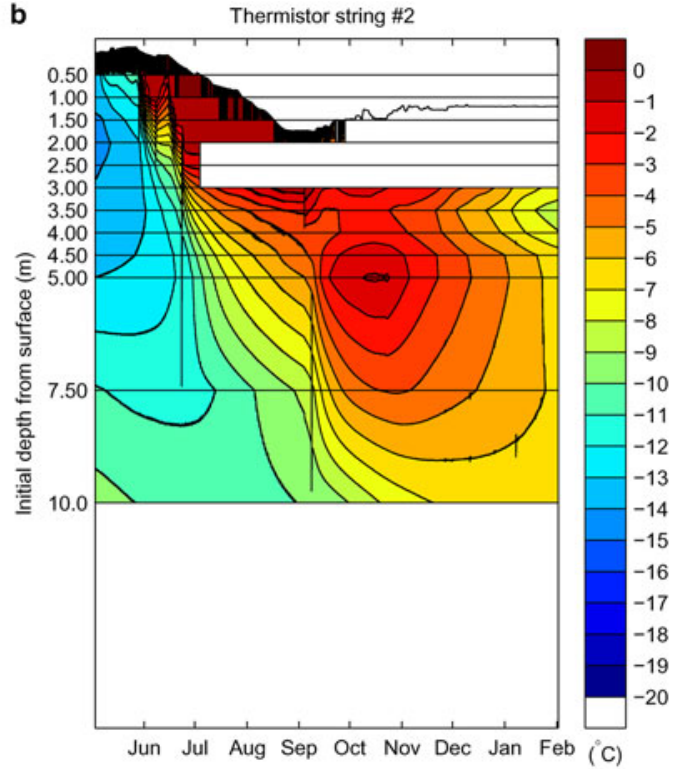

d

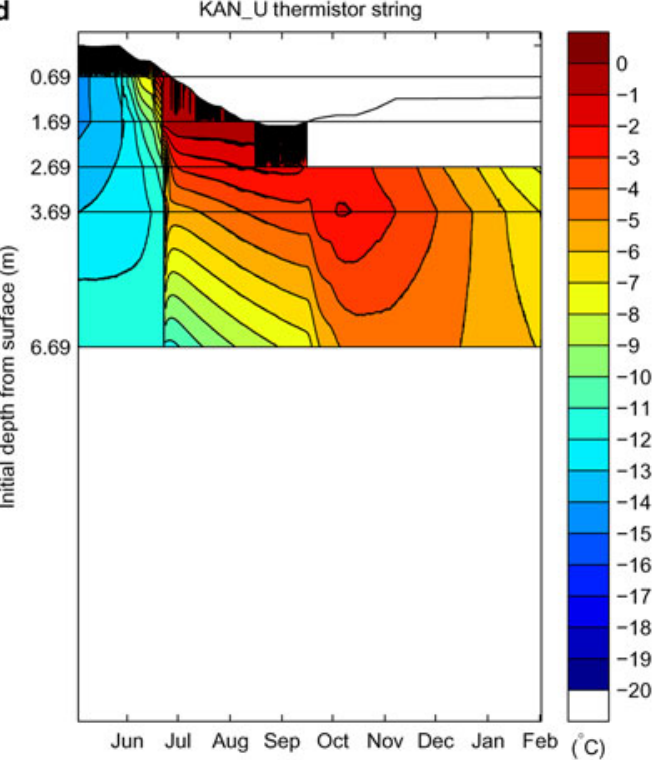

Fig. 3. Contour plots of firn temperatures in 2012 and 2013 as measured by the thermistor strings (a) main, (b) 2, (c) 3 and (d) KAN_U. The black horizontal lines indicate the installation depths of the thermistors.

1996). This discretization of daily latent heat release is used to prescribe increases in firn density associated with meltwater percolation to, and refreezing at, each vertical computational node. These density changes are mass-conserving within the entire vertical domain. Superimposed ice density is limited to a maximum of $870 \mathrm{~kg} \mathrm{~m}^{-3}$, which is consistent with the measured average density of ice layers in the 2012 firn cores. The heat conduction model is also contrasted against the full SPLAZ observation period, to place the observed firn temperature increase in the context of a baseline, and theoretical, conduction-only simulation.

\section{Uncertainties}

Drilling a hole for the installation of each thermistor string creates a pathway through the firn. Although the thermistor string holes in 2012 were carefully backfilled with drill chips and snow, there were cases of piping along the thermistors. They were recorded in the end of June when the generated meltwater was able to percolate at depths $>2 \mathrm{~m}$, and at the end of the melt season when meltwater was abundant at the surface (Fig. 2). These events were brief and did not have a lasting influence on the temperature profiles, which recovered in all cases immediately after the piping water refroze.

The distance between two successive thermistors along all utilized strings varies between 0.25 and $3 \mathrm{~m}$. As interpolation distances are greater than the characteristic distance scale over which the physical and thermal properties of firn can vary, the interpolation of firn temperature between thermistors smooths the actual temperature profile. The potential influence of this smoothing was minimized using smaller thermistor spacing closer to the surface, where temperature gradients are relatively great. The exact timing when ablation exposes the uppermost thermistors at the ice-sheet surface is uncertain, even though the surface height is monitored by sonic ranger. Since all surfacing thermistors are at or close to surface temperature, however, this uncertainty likely has a minor impact on our simulations.

The exact depth of each thermistor on the longer duration KAN_U string is more difficult to determine than for the 
shorter duration SPLAZ thermistor strings. However, the good agreement in observed firn temperatures at the KAN_U string and the SPLAZ strings during 2012 suggests that we calculated accurate absolute thermistor depths during the common observational period (Fig. 3). By comparing the deepest thermistor of the KAN_U string (Fig. 3d) with measurements from the main SPLAZ string (Fig. 3a) in May 2012, when the pre-melt season firn temperature profile should reflect only heat conduction, we estimate the depth uncertainty to be $<0.7 \mathrm{~m}$. As inferred depth uncertainty accumulates over time, a smaller uncertainty would be expected in years prior to 2012. On 28 April 2013, when a new thermistor string was installed, this uncertainty was reset.

The uncertainty introduced by radiative heating of the cables, and subsequent heat conduction toward thermistors, can be a potentially important issue in near-surface thermistor string measurements (Humphrey and others, 2012). The greatest challenge is to accurately capture the vertical temperature profile within the snow cover before and during the onset of melt, when the greatest temperature increases occur. However, Brandt and Warren (1993) concluded that radiative heating of thermistors is minimal at depths $>0.1 \mathrm{~m}$ after experimenting with shading the snow surface. In any case, in order to avoid artificial heat on our measurements, the monitoring of the snowpack in 2012 was by means of six high-precision temperature probes inserted horizontally in the snow and were, including their wires, covered by at least $15 \mathrm{~cm}$ at the onset of melt (Charalampidis and van As, 2015).

As described by Charalampidis and Van As (2015), the pure conduction model overestimates the diurnal cooling response within $0.2 \mathrm{~m}$ of the surface when lower density snow, rather than higher density firn, is present at the ice-sheet surface. This is likely due to shortwave radiation penetrating near-surface layers and delivering heat slightly below the surface (Colbeck, 1989a; Kuipers Munneke and others, 2009). However, this effect is minimal at greater depths, and therefore should not influence our identification of latent heat release due to refreezing meltwater as discrepancy from a pure conduction profile below $0.2 \mathrm{~m}$ depth. Due to the lack of topography and persistent strong winds at KAN_U, the cooling of the snowpack via wind ventilation should be negligible (Colbeck, 1989b; Bartlett and Lehning, 2011).

\section{RESULTS}

\section{Firn temperature and density}

The 2012 firn temperature measurements illustrate the progressive heating as meltwater percolates downward, and subsequently refreezes at depth, releasing latent heat (Fig. 3). Interpreting these observations, with respect to thermistor depths at installation, provides insight on the dominant heat transport processes during the observation period, as well as the firn depth to which meltwater percolated and refroze (Fig. 3)

In early June, meltwater percolation within the snow and firn is readily identifiable as a coherent warming front in all panels of Figure 3. Concurrent observations of surface lowering provide independent evidence of coincident melt. After the first $12 \mathrm{~d}$ of melt (27 May-7 June), temperatures in the uppermost meter of firn had increased to the melting point. No surface melt occurred between 8 and 12 June, during which time heat from this between $-1^{\circ} \mathrm{C}$ and $0^{\circ} \mathrm{C}$ temperate layer was conducted to $\sim 2 \mathrm{~m}$ depth. Melt began again on 13 June, and by 25 June the uppermost $2.0-2.5 \mathrm{~m}$ of snow and firn had reached $0^{\circ} \mathrm{C}$, due to a combination of heat conduction and meltwater percolation. The ice-sheet surface became water-saturated by mid-July, with substantial channelized surface runoff evident in both moderate and highresolution satellite imagery (Fig. 2).

Following the cessation of melt on 24 August, firn temperatures continued to increase by as much as $3{ }^{\circ} \mathrm{C} \mathrm{d}^{-1}$ below $2.5 \mathrm{~m}$ depth (Fig. 4a). Persistent subsurface heating, with temperatures exceeding $-2{ }^{\circ} \mathrm{C}$, was measured between 3 and $7 \mathrm{~m}$ depth throughout September-November (Fig. 3). The spatiotemporally isolated pockets of heating observed in the firn post-melt season infer meltwater refreezing (Fig. 3). During the event highlighted in Figure 4a, firn temperatures $\sim 6 \mathrm{~m}$ depth increased from $-6^{\circ} \mathrm{C}$ to $-1^{\circ} \mathrm{C}$ over a period of $3 \mathrm{~d}$ in early September (Fig. 4b). The temperature between 5.5 and $6.0 \mathrm{~m}$ then remained above $-1{ }^{\circ} \mathrm{C}$ until mid-October (Fig. 3a). By this time, however, temperatures in the uppermost meter of the firn had already dropped in response to low air temperatures, as heat was conducted from the near-surface firn toward the atmosphere.

In general, the most pronounced refreezing events occurred between 3 and $6 \mathrm{~m}$ depth (Fig. 3), as verified also by the 2013 firn core (Fig. 4c). Differencing the long (15 m) firn temperature profiles measured at 00.00 UTC by the temporally analogous conduction-model profiles, suggests that $0.40 \mathrm{~m}$ w.e. of meltwater refroze in the upper $9 \mathrm{~m}$ of the firn column. Simulations suggest this substantial refreezing occurred at firn depths of 2.0-2.5, 5.0-6.0 and 8.0-9.0 m (Fig. 5). The greatest increase in simulated density, $>300 \mathrm{~kg} \mathrm{~m}^{-3}$, was at $2 \mathrm{~m}$ depth below the May 2012 surface. Simulated refreezing between 8 and 9 $m$ depth suggests an increase in firn density $>200 \mathrm{~kg} \mathrm{~m}^{-3}$. We find evidence neither of meltwater percolating and refreezing below $9 \mathrm{~m}$ depth, nor complete filling of pore volume above.

Although little or no meltwater reached $10 \mathrm{~m}$ depth or below in the exceptional 2012 melt season, the latent heat released in overlying firn did appear to significantly influence the temperature at those depths. Across all thermistor strings, the average $10 \mathrm{~m}$ firn temperature was $-8.7^{\circ} \mathrm{C}$, ranging from $-10.5^{\circ} \mathrm{C}$ to $-6.0^{\circ} \mathrm{C}$ between thermistors. At $15 \mathrm{~m}$ depth, the average temperature was $-9.7^{\circ} \mathrm{C}$, ranging from $-10^{\circ} \mathrm{C}$ to $-9.0^{\circ} \mathrm{C}$. On 1 February, measured firn temperature at $10 \mathrm{~m}$ depth was $-6.8^{\circ} \mathrm{C}$ and $-6.5^{\circ} \mathrm{C}$, exceeding the simulated conduction-only temperature by $4.2^{\circ} \mathrm{C}-4.5^{\circ} \mathrm{C}$. Significantly less affected was the temperature at $15 \mathrm{~m}$ depth where on 1 February was $-9.0^{\circ} \mathrm{C}$, exceeding the simulated conduction-only temperature by $1.7^{\circ} \mathrm{C}$. Compared with the conduction-only simulations, during the 9 month study period the firn warmed by an average of $4.7^{\circ} \mathrm{C}$ between 2 and $15 \mathrm{~m}$ depth.

\section{Interannual perspective}

The 4.5-year long, albeit at shallower depths (maximum 9.5 m; Charalampidis and others, 2015), firn temperature measurements from the KAN_U AWS document the firn's thermal response to a variety of surface conditions, including the high-melt years of 2010 and 2012. Interpreting these observations with respect to the thermistors' depths relative to the ice-sheet surface reveals the interannual variability of the thermal state of firn (Fig. 6). 

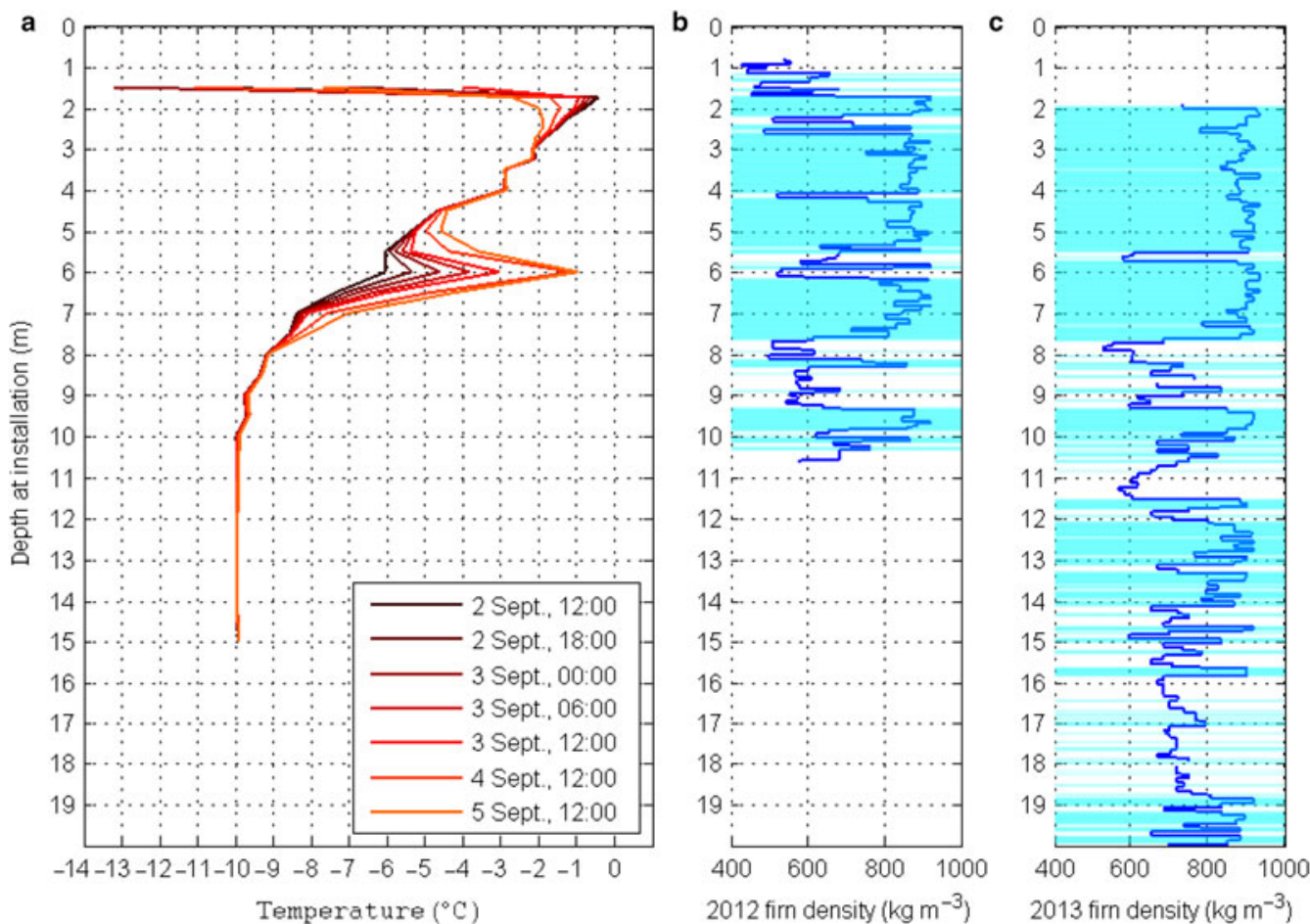

Fig. 4. (a) Firn temperature profiles highlighting a refreezing event at $6 \mathrm{~m}$ depth in early September 2012. Time is in UTC. Solar zenith time at KAN_U is at 15.08 UTC. (b) Measured firn densities from a firn core recovered before the 2012 melt season. (c) Measured firn densities from a firn core recovered after the 2012 melt season.

In all years, during the melt season, the percolating meltwater formed a temperate layer within the snow and firn. During the 2009 melt season, the temperate surface layer remained close to the surface, while reached $\sim 2 \mathrm{~m}$ depth for only $5 \mathrm{~d}$ in late July (Fig. 6). By contrast, during the 2010 melt season, a well-defined temperate layer reached up to $\sim 3 \mathrm{~m}$ in July, while melt occurred until the beginning of September. Similarly to 2010, a temperate layer also

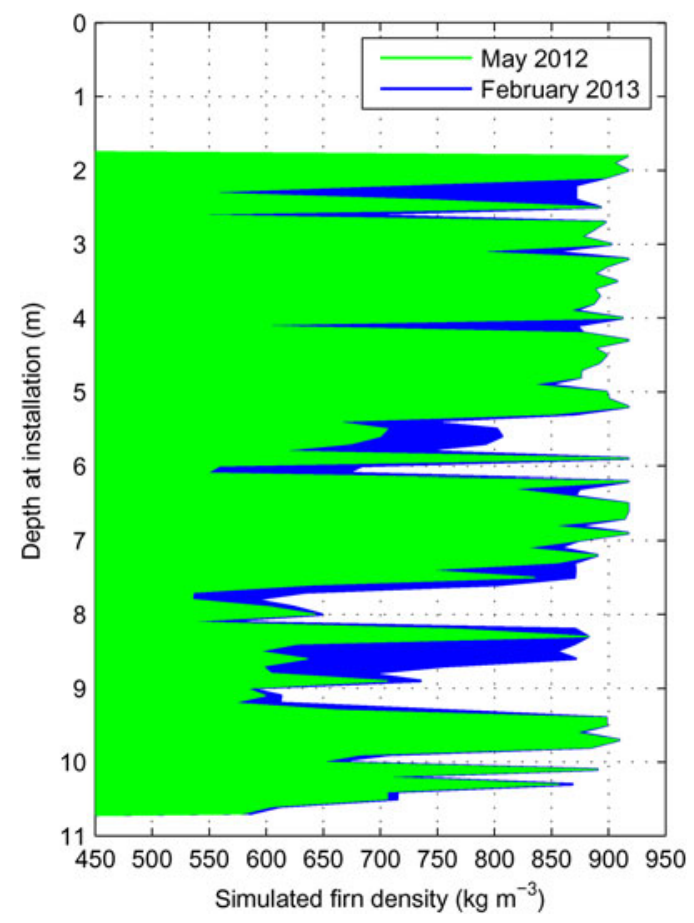

Fig. 5. Observed firn density profile in May 2012 (green) and simulated profile in February 2013 (blue). formed in the warmer-than-average 2011 melt season. The 2011 temperate layer reached $\sim 2 \mathrm{~m}$ depth in mid-July, while melt ceased in mid-August. Both in 2010 and 2011 melt seasons, the downward progression of the temperate layer was proportional to surface ablation, thus maintaining approximately constant thickness (Fig. 6). In both cases, the temperate layer persisted until well after the end of the melt season, and disappeared in the beginning of October in 2010 and in mid-September in 2011 (Fig. 6; Charalampidis and others, 2015). During the 2012 melt season, the temperate layer reached $2.0-2.5 \mathrm{~m}$ by 25 June. On 24 August, at the end of the melt season, the temperate layer was $0.50-0.75 \mathrm{~m}$ thick, and it disappeared quickly compared with 2010 and 2011, following the onset of low air temperatures in early September (Figs 3 and 6).

The warm melt seasons of 2010-12 were followed by the relatively cold melt season of 2013. At the onset of melt in 2013, the accumulated snowpack on top of the 2012 surface was $\sim 1.3 \mathrm{~m}$ (Charalampidis and others, 2015). A temperate layer formed for 2 weeks in late July 2013 within the uppermost half meter of the snowpack. The temperature at $1 \mathrm{~m}$ depth (approximately the 2012 surface) did not exceed $-1^{\circ} \mathrm{C}$, and at $2 \mathrm{~m}$ depth temperatures remained below $-4.3^{\circ} \mathrm{C}$, throughout the melt season (Fig. 6).

The consideration of average summer (JJA) and winter DJF (December-February) firn temperatures at specific depths (Table 1) reveals the seasonal changes in thermal state, as well as the long-term thermal evolution of the firn. Differences of summer firn temperatures between different years are primarily due to the interannual variability of melt. During summer 2010, firn between 2 and $6 \mathrm{~m}$ depth was $1.3^{\circ} \mathrm{C}$ warmer than in 2009 (Table 1) as a result of twice as much available meltwater (Charalampidis and others, 2015). The diffusive effect of the 2010 melt persisted until summer 2011 when, although lower firn temperatures 

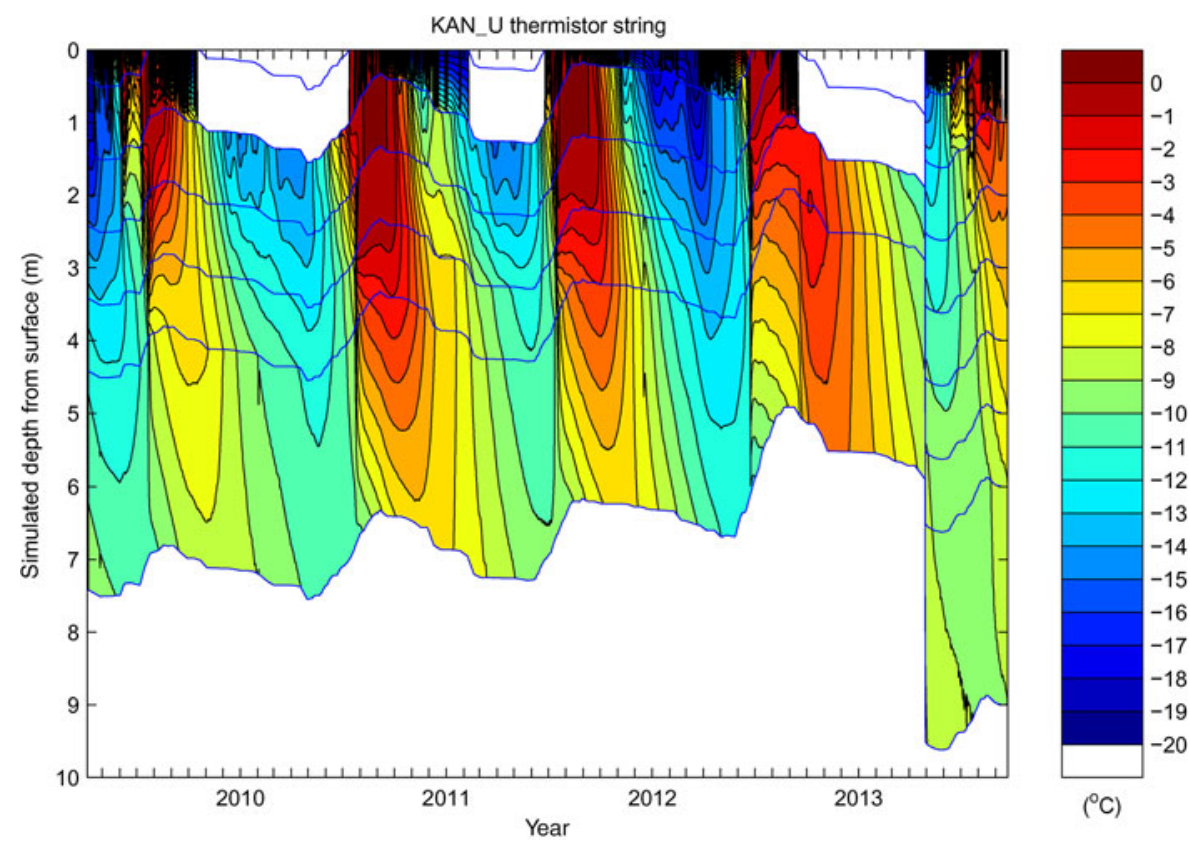

Fig. 6. Firn temperatures measured at the KAN_U weather station. The blue lines indicate the position of the thermistors below the surface. The white areas near the surface are due to surfaced thermistors. We note that the thermistor string was replaced by a new one on 28 April 2013.

compared with 2010 were observed at $2-5$ m depth, firn at 6 $\mathrm{m}$ depth was warmer by $0.3^{\circ} \mathrm{C}$. We note that in both summers 2010 and 2011, firn below $~ 5 \mathrm{~m}$ depth was cooler than in the preceding winters, indicating refreezing primarily closer to the surface.

The comparison of winter firn temperatures with the firn temperatures in the preceding summers reveals the seasonal cooling response of the firn. In winters 2009/10 and 2010/11, the firn was on average cooler than in the preceding summers, although it was warmer between 4 and $6 \mathrm{~m}$ depth $\left(+0.5^{\circ} \mathrm{C}\right.$ in $2009 / 10,+1.8^{\circ} \mathrm{C}$ in $\left.2010 / 11\right)$, highlighting the insulating effect of autumn snow cover. In both cases, the temperature anomaly relative to the preceding summer was $\sim 0^{\circ} \mathrm{C}$ between 3 and $4 \mathrm{~m}$ depth. Overall, for the period 2009-11, bulk firn temperature increased by $0.4^{\circ} \mathrm{C}$ (equivalent to $\mathrm{a}+0.2{ }^{\circ} \mathrm{C} \mathrm{a}^{-1}$ warming trend). We note that the late snow cover in winter 2011/12 only became thick enough after February (Charalampidis and others, 2015), thus leaving the firn with limited insulation in autumn.

In summer 2012, despite the earlier development of a temperate layer, ablation was nearly double than in summer 2011 (Charalampidis and others, 2015), thus conducted heat remained close to the surface. However, due to the late refreezing (Fig. 3) and the early snow cover in autumn 2012 (Charalampidis and others, 2015), the firn between 2 and $5 \mathrm{~m}$ depth in winter 2012/13 was the warmest on record with an average temperature of $-6.1^{\circ} \mathrm{C}$, and was even warmer than in the preceding summer.

Summer 2013 was the only summer with significantly colder firn than in the preceding winter $\left(-2.7^{\circ} \mathrm{C} ; 2-5 \mathrm{~m}\right.$ depth). This was due to the combination of relatively low melt (comparable with 2009; Charalampidis and others, 2015), as well as suppressed vertical percolation by the thick superimposed ice at the 2012 melt surface. However, even though there was no significant percolation below $\sim 1 \mathrm{~m}$ depth, firn at 4-6 $\mathrm{m}$ depth was warmer by $0.6^{\circ} \mathrm{C}$ than in summer 2009 ; equivalent to a $+0.15^{\circ} \mathrm{C} \mathrm{a}^{-1}$ warming trend over the 2009-13 period. This illustrates how the extreme conditions of previous summers can persist to influence the thermal state of firn in subsequent summers.

Table 1. Summer (JJA) and winter (DJF) average firn temperatures $\left({ }^{\circ} \mathrm{C}\right)$, linearly interpolated to specific depths at KAN_U

\begin{tabular}{|c|c|c|c|c|c|}
\hline $\begin{array}{l}\text { Depth } \\
\mathrm{m}\end{array}$ & 2009 & 2010 & 2011 & 2012 & 2013 \\
\hline \multicolumn{6}{|c|}{ Summer $(J J A)$} \\
\hline 2 & -6.0 & -4.7 & -5.4 & -5.6 & -7.7 \\
\hline 3 & -8.3 & -6.5 & -7.0 & -7.0 & -8.9 \\
\hline 4 & -9.7 & -8.0 & -8.3 & -8.3 & -9.2 \\
\hline 5 & -9.9 & -8.8 & -8.9 & - & -9.3 \\
\hline 6 & -10.1 & -9.7 & -9.4 & - & -9.4 \\
\hline \multicolumn{6}{|c|}{ Following winter (DJF) } \\
\hline 2 & -12.7 & -9.6 & -12.5 & -6.7 & - \\
\hline 3 & -11.1 & -7.6 & -10.6 & -6.1 & - \\
\hline 4 & -9.7 & -7.0 & -9.6 & -5.9 & - \\
\hline 5 & -9.3 & -7.0 & -9.0 & -5.8 & - \\
\hline 6 & -9.1 & -7.0 & -8.3 & - & - \\
\hline
\end{tabular}




\section{DISCUSSION}

\section{Firn and warming atmosphere}

The thickness of the near-surface temperate firn layer in the LAA is indirectly influenced by the surface energy balance, and directly influenced by available meltwater. In the summers of 2010 and 2011, once developed, the temperate layer remained approximately constant in thickness, progressing downward in tandem with surface lowering. This suggests that pore volume was available for retaining meltwater between 2 and $3 \mathrm{~m}$ beneath the surface. In both the years, the temperate layer was present for a relatively long period after the cessation of melt, suggesting that the retained meltwater slowly refroze in response to cold content introduced by relatively low air/surface temperatures. Meltwater refreezing at these depths would imply a substantial increase in near-surface firn density. A lack of direct observations prevents us from ascertaining whether meltwater saturated the firn overlying ice layers in the 2010 and 2011 melt seasons. In the 2012 melt season, however, meltwater percolation was indeed observed to be substantially delayed, or prevented, by thick superimposed ice layers (Figs 3 and 4b). The percolation blockage resulted in the confinement of meltwater, and therefore also of the temperate layer, between the surface and the superimposed ice layers. This effect combined with the concurrent surface ablation resulted in thinning of the temperate layer in late June and eventually surface runoff later in the melt season. In response to freezing atmospheric conditions between 24 August and early September 2012, at least a portion of the remaining meltwater within the uppermost saturated firn refroze as distinctive superimposed ice perched above the pre-existing ice layers (Charalampidis and others, 2015).

Temporally isolated superimposed ice layer formation events generally have limited consequences on meltwater percolation, as long as sufficient new pore volume is generated by winter snow fall between events. However, when multiple high-melt summers are closely spaced in time, there may not be sufficient intervening winter snow accumulation to completely accommodate meltwater in permeable layers. A tipping point in meltwater retention may be reached when superimposed ice layers from multiple melt seasons merge, and permeability and retention capacity are reduced, especially in the top $5 \mathrm{~m}$ of the firn column. We suggest that this merging of annual ice layers occurred in 2010 and 2011, providing a partial, or full, barrier to 2012 percolation, as inferred by the temperate layer thinning we observed. We further speculate that such merging of annual ice layers may have occurred at KAN_U during previous exceptionally warm melt seasons, such as 2003 and 2007 (Van As and others, 2012).

The relatively thin 2012 temperate layer responded faster to atmospheric cooling in autumn than in previous years. Shortly after air temperatures had decreased, newly accumulated snow insulated the firn surface from the atmosphere. The delayed latent heat release at depth implies that meltwater was retained within the firn until 2 months after the end of the 2012 melt season. The firn core density increases inferred by comparison of the two cores between spring 2012 and 2013 (Figs 4b and c; Machguth and others, 2016) suggest that negligible meltwater percolated, and refroze, below $6 \mathrm{~m}$ depth (Fig. 7). Although our simulated density changes generally match these observations, they infer that in 2012 meltwater refroze as deep as 8-9 $\mathrm{m}$ (Fig. 7).

Both firn cores and firn temperatures represent point measurements of the inherently stochastic, and spatiotemporally

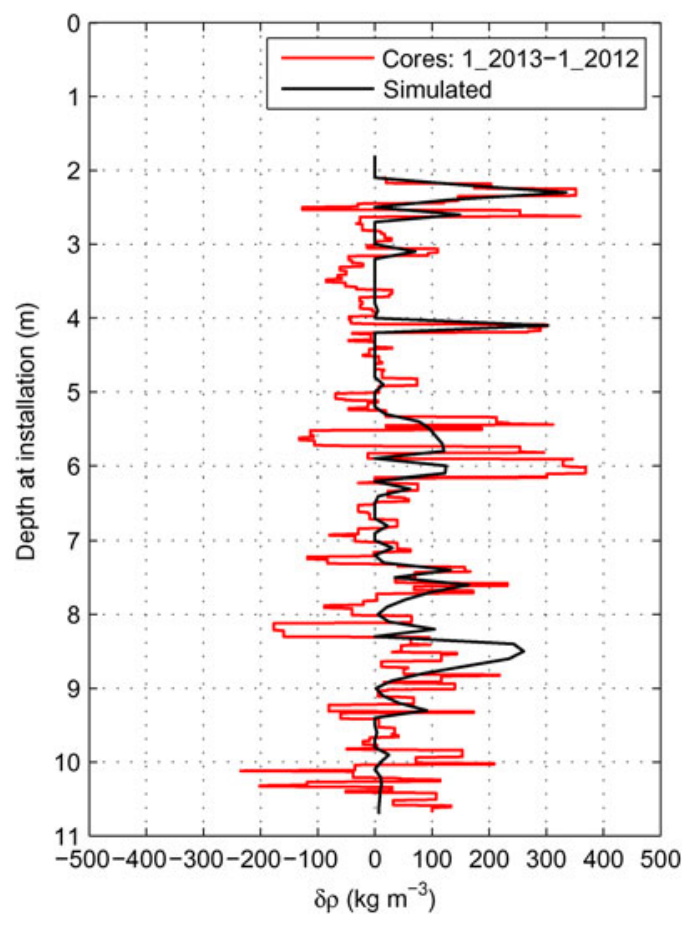

Fig. 7. Simulated 2012 firn density changes (black) and observed change by differencing May 2012 and 2013 firn density profiles (red).

heterogeneous, processes of meltwater percolation and ice lens formation within unsaturated firn. Hence, appreciable uncertainty is associated both with the inferred density changes and simulated penetration depths. Firstly, the core comparison indicates physically implausible density decrease at certain depths, which is simply a result of the heterogeneity of firn stratigraphy over spatial scales as short as the distance between the two drill sites ( $\sim 10 \mathrm{~m}$ apart). Then again, observed density increase cannot automatically be related to refreezing, as it could also result from firn heterogeneity. Filtering out the effects of firn heterogeneity requires averaging over a larger number of point measurements (not shown; cf. Machguth and others, 2016). Secondly, adopting a 1-D model enforces mass conservation within the column domain, and implicitly prohibits lateral percolation into, and out of, the column domain. Our simulated changes in density profile should therefore be consistent with firn density profiles averaged over a horizontal distance greater than the characteristic length scale of horizontal percolation. Nevertheless, both the thermistor strings and firn cores suggest that meltwater did not percolate to pore volume below $9 \mathrm{~m}$, nor completely filled the pore volume above, at KAN_U in 2012 (Fig. 7).

\section{$10 \mathrm{~m}$ temperature}

Mock and Weeks (1966) presented the distribution of $10 \mathrm{~m}$ firn temperatures across Greenland based on 112 in situ observations from prior to 1965. The in situ observation closest to our study site that they employ was approximately $60 \mathrm{~km}$ south/southwest of KAN_U. According to their analysis, the estimated $10 \mathrm{~m}$ firn temperature at KAN_U should be approximately $-14^{\circ} \mathrm{C}$. The present-day average annual air temperature at KAN_U does indeed broadly satisfy this estimate; in 2012 the annual air temperature was $-14.3^{\circ} \mathrm{C}$ (Charalampidis and others, 2015). As described above, however, the average $10 \mathrm{~m}$ firn temperature we observed at KAN_U was substantially warmer: $-8.7^{\circ} \mathrm{C}$. Assuming 
that during the 1960s our study site was in a dry firn regime, the thermal effect of refreezing has increased firn temperatures by an average of $\sim 0.1^{\circ} \mathrm{Ca}^{-1}$. Our estimate of heat input to the firn over the years $2009-13$ is $50 \%$ greater than this, which highlights the highly transient nature of recent climate. Similar mismatches between observed average annual $10 \mathrm{~m}$ firn and near-surface air temperatures have been reported by more recent studies (Steffen and Box, 2001; Humphrey and others, 2012).

Ten-meter firn temperatures do not reflect conductive temperature wave propagation, especially where deep percolation is known to occur (Polashenski and others, 2014), which is a large region of the Southwestern Greenland ice sheet. Machguth and others (2016) show that percolation down to $10 \mathrm{~m}$ depth occurs, under some conditions, at elevations up to at least $2142 \mathrm{~m}$ a.s.l., which is at least $110 \mathrm{~km}$ inland from the ELA of the Kangerlussuaq region and $195 \mathrm{~km}$ inland from the ice margin. While conventionally assumed to be characteristic of average annual air temperatures (Mock and Weeks, 1966; Benson, 1962), $10 \mathrm{~m}$ firn temperature now appears to deviate significantly from average annual air temperature over a substantial portion of this ice sheet.

\section{CONCLUSIONS}

Firn temperature measurements from the LAA of the Southwestern Greenland ice sheet suggest that during the 2012 extreme melt season, meltwater percolation below $2.5 \mathrm{~m}$ depth was suppressed due to superimposed ice lenses of $\sim 5.5 \mathrm{~m}$ thickness previously generated in recent years. This transient stratigraphy resulted in unprecedented meltwater saturation of the near-surface firn during the 2012 melt season. Simulations suggest that refreezing eventually occurred at 2.0-2.5, 5.0-6.0 and 8.0-9.0 $\mathrm{m}$ depth, but only well after the end of the melt season, presumably following the slow development of hydraulic pathways to pore volume with available cold content. Despite the abundance of meltwater at the surface during the melt season, which supersaturated near-surface firn, appreciable vertical meltwater percolation was observed neither to exceed $9 \mathrm{~m}$ depth, nor to fill all available pore volume above.

After the extreme 2012 melt season, the delayed latent heat release associated with refreezing meltwater counteracted wintertime cooling of the firn, resulting in above normal firn temperatures throughout winter. By comparison with conduction-only simulated firn temperature profiles, the latent heat released in the upper firn appears to have increased the firn temperature at $10 \mathrm{~m}$ depth by $4.2^{\circ} \mathrm{C}-4.5^{\circ} \mathrm{C}$ and at $15 \mathrm{~m}$ depth by $1.7^{\circ} \mathrm{C}$. Overall, the effect of refreezing on firn temperature was $+4.7^{\circ} \mathrm{C}$ on average between 2 and $15 \mathrm{~m}$ depth.

The analysis of 4.5-a long firn temperature measurements from the adjacent KAN_U AWS revealed the formation of a 2-3 $\mathrm{m}$ thick temperate layer within the firn close to the surface during 2010 and 2011 summers of high melt. The inferred high liquid water content within this layer led to the formation of ice by mid- to late September in these years. Due to the succession of high melt summers, these superimposed annual ice layers merged within the firn, leading to a situation where little pore volume was subsequently available in the upper firn column in 2012, which was also the most pronounced melt season over the investigated time period. The firn warming from 2009 to 2013 was $+0.15^{\circ} \mathrm{C} \mathrm{a}^{-1}$.

The combined effects of delayed refreezing at depth, increased heat conductivity due to high ice content and thermal insulation by snow cover, sustained relatively high firn temperatures in winter 2012/13. During anticipated future warm melt seasons, which may be analogous to 2012, the temperate layer within the firn will be able to expand only to the depth of pre-existing massive superimposed ice lenses; meltwater will accumulate as further superimposed ice on top of these ice lenses. Forecasted increases in atmospheric temperatures, and corresponding melt, will likely result in the thickening and up-glacier migration of superimposed ice layers. We speculate that this will transform the current LAA into a superimposed ice area relatively quickly, in which potentially underlying firn pore volume will remain isolated at depth, reducing the icesheet wide meltwater buffering capacity. In combination with enhanced meltwater production due to the melt-albedo feedback, this will result in even more surface runoff and mass loss from the historical LAA.

\section{ACKNOWLEDGEMENTS}

We are grateful to three anonymous reviewers and the scientific editor Joel Harper for constructive comments, and we thank Signe H. Larsen for valuable discussions. We are also grateful to our Snow Processes in the Lower Accumulation Zone (SPLAZ) fellow expedition members Andreas Mikkelsen, Rickard Pettersson, Katrin Lindbäck, Alun Hubbard and Samuel Doyle. The KAN_U weather station was funded by the nuclear waste management organizations in Sweden (Svensk Kärnbränslehantering $\mathrm{AB}$ ), Finland (Posiva Oy) and Canada (NWMO) through the Greenland Analogue Project (GAP Sub-Project A). It is operated by the Geological Survey of Denmark and Greenland (GEUS) with 2009-12 logistical, technical and manpower support from Aberystwyth University funded through the UK Natural Environmental Research Council (NERC grant NE/G005796/1), a Royal Geographical Society (RGS) Gilchrist Fieldwork Award to Alun Habbard, and an Aberystwyth University doctoral scholarship to Samuel Doyle. Technical and salary support were received from the Programme for Monitoring of the Greenland Ice Sheet (PROMICE), launched and funded by the Danish Energy Agency (Energistyrelsen) under the Danish Ministry of Energy, Utilities and Climate, and within the Danish Cooperation for Environment in the Arctic (DANCEA). This is a PROMICE publication and contribution number 67 of the Nordic Centre of Excellence SVALI, 'Stability and Variations of Arctic Land Ice', funded by the Nordic Top-level Research Initiative (TRI). Satellite imagery in Figure 2 is subject to copyright by European Space Imaging / DigitalGlobe.

\section{REFERENCES}

Bartlett SJ and Lehning M (2011) A theoretical assessment of heat transfer by ventilation in homogeneous snowpacks. Water Resour. Res., 47, W04503 (doi: 10.1029/2010WR010008)

Bennartz R and 8 others (2013) Greenland melt extent enhanced by low-level liquid clouds. Nature, 496, 83-86 (doi: 10.1038/ Nature12002)

Benson CS (1962) Stratigraphic studies in the snow and firn of the Greenland ice sheet. Research Report, vol. 70, Snow, Ice, and Permafrost Research Establishment (SIPRE), US Army Corps of Engineers, reprinted with revisions in 1996 by the Cold Regions Research and Engineering Laboratory (CRREL), Hanover, New Hamshire, USA, 182 pp.

Bezeau P, Sharp M, Burgess D and Gascon G (2013) Firn profile changes in response to extreme 21 st-century melting at Devon 
Ice Cap, Nunavut, Canada. J. Glaciol., 59, 981-991 (doi: 10.3189/2013JoG12J208)

Bøggild CE, Forsberg R and Reeh N (2005) Meltwater retention in a transect across the Greenland ice sheet. Ann. Glaciol., 40, 169173 (doi: 10.3189/172756405781813546)

Box JE and 5 others (2012) Greenland ice sheet albedo feedback: thermodynamics and atmospheric drivers. Cryosphere, 6, 821839 (doi: 10.5194/tc-6-821-2012)

Brandt RE and Warren SG (1993) Solar-heating rates and temperature profiles in Antarctic snow and ice. J. Glaciol., 39, 99-110

Charalampidis C and Van As D (2015) Observed melt-season snowpack evolution on the Greenland ice sheet. Geol. Surv. Denmark Greenland Bull., 33, 65-68

Charalampidis $C$ and 9 others (2015) Changing surface-atmosphere energy exchange and refreezing capacity of the lower accumulation area, West Greenland. Cryosphere, 9, 2163-2181 (doi: 10.5194/tc-9-2163-2015)

Citterio $\mathrm{M}$ and 10 others (2015) Automatic weather stations for basic and applied glaciological research. Geol. Surv. Denmark Greenland Bull., 33, 69-72

Clausen HB, Gundestrup NS, Johnsen SJ, Bindschadler R and Zwally J (1988) Glaciological investigations in the Crete Area, Central Greenland: a search for a new deep-drilling site. Ann. Glaciol., 10, 10-15

Colbeck SC (1989a) Snow-crystal growth with varying surface temperatures and radiation penetration. J. Glaciol., 35, 23-29

Colbeck SC (1989b) Air movement in snow due to windpumping. J. Glaciol., 35, 209-213

Cuffey KM and Paterson WSB (2010) The physics of glaciers, 4th edn. Elsevier, Butterworth-Heinemann, 704 pp

De la Peña S and 7 others (2015) Changes in the firn structure of the western Greenland ice sheet caused by recent warming. Cryosphere, 9, 1203-1211 (doi: 10.5194/tc-9-1203-2015)

Enderlin EM and 5 others (2014) An improved mass budget for the Greenland ice sheet. Geophys. Res. Lett., 41, 866-872 (doi: 10.1002/2013GL059010)

Gascon G, Sharp MJ, Burgess DO, Bezeau P and Bush A (2013) Changes in accumulation area firn stratigraphy and meltwater flow during a period of climate warming, Devon Ice Cap, Nunavut, Canada. J. Geophys. Res., 118, 2380-2391 (doi: 10.1002/2013JF002838)

Hall DK and 5 others (2013) Variability in the surface temperature and melt extent of the Greenland ice sheet from MODIS. Geophys. Res. Lett., 40, 2114-2120 (doi: 10.1002/grl.50240)

Hanna E and 8 others (2014) Atmospheric and oceanic climate forcing of the exceptional Greenland ice sheet surface melt in summer 2012. Int. J. Climatol., 34, 1022-1037 (doi: 10.1002/joc.3743)

Harper J, Humphrey N, Pfeffer WT, Brown J and Fettweis X (2012) Greenland ice-sheet contribution to sea-level rise buffered by melt water storage in firn. Nature, 491, 240-243 (doi: 10.1038/ nature11566)

Humphrey N, Harper J and Pfeffer W (2012) Thermal tracking of meltwater retention in Greenland's accumulation area. J. Geophys. Res., 117, F01010 (doi: 10.1029/2011JF002083)

Keegan KM, Albert MR, McConnell JR and Baker I (2014) Climate change and forest fires synergistically drive widespread melt events of the Greenland ice sheet. Proc. Natl. Acad. Sci. U.S.A., 111, 7964-7967 (doi: 10.1073/pnas.1405397111)

Koenig LS, Miège C, Forster RR and Brucker L (2014) Initial in situ measurements of perennial meltwater storage in the Greenland firn aquifer. Geophys. Res. Lett., 41, 1-5 (doi: 10.1002/2013GL058083)

Kuipers Munneke P and 6 others (2009) The role of radiation penetration in the energy budget of the snowpack at Summit, Greenland. Cryosphere, 3, 155-165 (doi: 10.5194/tc-3-155-2009)

Lüthi MP and 7 others (2015) Heat sources within the Greenland Ice Sheet: dissipation, temperate paleo-firn and cryo-hydrologic warming. Cryosphere, 9, 245-253 (doi: 10.5194/tc-9-245-2015)

Machguth $\mathrm{H}$ and 9 others (2016) Greenland meltwater storage in firn limited by near-surface ice formation. Nat. Clim. Change, 6, 390-393 (doi: 10.1038/nclimate2899)
McGrath D, Colgan W, Bayou N, Muto A and Steffen K (2013) Recent warming at Summit, Greenland: global context and implications. Geophys. Res. Lett., 40, 2091-2096 (doi: 10.1002/grl.50456)

Mock SJ and Weeks WF (1966) The distribution of 10 meter snow temperatures on the Greenland ice sheet. J. Glaciol., 6, 23-41

Nghiem SV and 8 others (2012) The extreme melt across the Greenland ice sheet in 2012. Geophys. Res. Lett., 39, L20502 (doi: 10.1029/2012GL053611)

Pfeffer W and Humphrey N (1996) Determination of timing and location of water movement and ice-layer formation by temperature measurements in sub-freezing snow. J. Glaciol., 42, 292-304

Pfeffer W, Meier M and Illangasekare TH (1991) Retention of Greenland runoff by refreezing: implications for projected future sea level change. J. Geophys. Res., 96, 22117-22124 (doi: 10.1029/91JC02502)

Phillips T, Rajaram H and Steffen K (2010) Cryohydrologic warming: a potential mechanism for rapid thermal response of ice sheets. Geophys. Res. Lett., 37, L20503 (doi: 10.1029/2010GL044397)

Phillips T, Rajaram H, Colgan W, Steffen K and Abdalati W (2013) Evaluation of cryo-hydrologic warming as an explanation for increased ice velocities in the wet snow zone, Sermeq Avannarleq, West Greenland. J. Geophys. Res.-Earth Surf., 118, 1241-1256 (doi: 10.1002/jgrf.20079)

Polashenski C and 7 others (2014) Observations of pronounced Greenland ice sheet firn warming and implications for runoff production. Geophys. Res. Lett., 41, 4238-4246 (doi: 10.1002/ 2014GL059806)

Shepherd A and 45 others (2012) A reconciled estimate of ice-sheet mass balance. Science, 338, 1183-1189 (doi: 10.1126/ science.1228102)

Steffen K and Box J (2001) Surface climatology of the Greenland ice sheet: Greenland Climate Network 1995-1999. J. Geophys. Res., 106, 33951-33964 (doi: 10.1029/2001JD900161)

Sturm M, Holmgren J, Köning M and Morris K (1997) The thermal conductivity of seasonal snow. J. Glaciol., 43, 26-41

Tedesco M and 6 others (2013) Evidence and analysis of 2012 Greenland records from spaceborne observations, a regional climate model and reanalysis data. Cryosphere, 7, 615-630 (doi: 10.5194/tc-7-615-2013)

Van Angelen JH, Lenaerts JTM, Van den Broeke MR, Fettweis X and Meijgaard E (2013) Rapid loss of firn pore space accelerates 21st century Greenland mass loss. Geophys. Res. Lett., 40, 21092113 (doi: 10.1002/grl.50490)

Van As D (2011) Warming, glacier melt and surface energy budget from weather station observations in the Melville Bay region of northwest Greenland. J. Glaciol., 57, 208-220 (doi: 10.3189/ $002214311796405898)$

Van As D and 5 others (2012) Large surface melt water discharge from the Kangerlussuaq sector of the Greenland ice sheet during the record-warm year 2010 explained by detailed energy balance observations. Cryosphere, 6, 199-209 (doi: 10.5194/tc-6-199-2012)

Van As D, Fausto RS, Colgan WT and Box JE and The PROMICE Project Team (2013) Darkening of the Greenland ice sheet due to the melt-albedo feedback observed at the PROMICE weather stations. Geol. Surv. Denmark Greenland Bull., 28, 69-72

Van As D, Fausto RS and Steffen K and The PROMICE Project Team (2014) Katabatic winds and piteraq storms: observations from the Greenland ice sheet. Geol. Surv. Denmark Greenland Bull., 31, 83-86

Van de Wal RSW and 5 others (2012) Twenty-one years of mass balance observations along the K-transect, West Greenland. Earth Syst. Sci. Data, 4, 31-35 (doi: 10.5194/essd-4-31-2012)

Vernon CL and 6 others (2013) Surface mass balance model intercomparison for the Greenland ice sheet. Cryosphere, 7, 599614 (doi: 10.5194/tc-7-599-2013)

Yen YC (1981) Review of thermal properties of snow, ice and sea ice. CRREL Report, vol. 81, US Army Corps of Engineers, Cold Regions Research and Engineering Laboratory, Hanover (CRREL), New Hamshire, USA, 34 pp 